\title{
Myocardial Localization and Isoforms of Neural Cell Adhesion Molecule (N-CAM) in the Developing and Transplanted Human Heart
}

\author{
Lee Gordon, ${ }^{*}$ John Wharton, ${ }^{*}$ Stephen E. Moore, Frank S. Walsh, J. Gonzalo Moscoso, ${ }^{\ddagger}$ Richard Penketh, ${ }^{5}$ John Wallwork," \\ Kenneth M. Taylor,' Magdi H. Yacoub, and Julia M. Polak* \\ Departments of ${ }^{*}$ Histochemistry, ${ }^{8}$ Obstetrics and Gynaecology, and 'Surgery, Royal Postgraduate Medical School, London W12 ONN, \\ United Kingdom; Department of Neurochemistry, Institute of Neurology, London WCIN $3 B G$, United Kingdom; ${ }^{\ddagger}$ Department of \\ Morbid Anatomy, Kings College Hospital, London SE5 8RX, United Kingdom; "The Transplant Unit, Papworth Hospital, \\ Papworth Everard, Cambridge CB3 8RE, United Kingdom; and The Cardiothoracic Unit, Harefield Hospital, Harefield, \\ Middlesex UB9 6JH, United Kingdom
}

\begin{abstract}
Neural cell adhesion molecule (N-CAM) has been implicated in cellular interactions involved in cardiac morphogenesis and innervation. Immunohistochemical techniques and Western blot analysis were used to determine the localization and isoforms of N-CAM in the developing and extrinsically denervated human heart. Myocardial and conducting cells in the fetal heart (7-24 wk gestation) exhibited sarcolemmal immunoreactivity, the major desialo N-CAM isoforms being 150 , $145,120,115$, and $110 \mathrm{kD}$. N-CAM expression appeared to be downregulated in the myocardium during adult life, with relatively little sarcolemmal immunoreactivity being detected in normal donor tissues. In contrast to the temporal changes observed in the myocardium, both the developing and mature cardiac innervation displayed N-CAM immunofluorescence staining, localized to neuronal cell bodies, nerve fascicles and fibres. Extrinsically denervated cardiac allografts, obtained 2 d to 91 mo after transplantation, showed extensive sarcolemmal and intercalated disc immunostaining and expression of 125-, 120-, and 115-kD isoforms. Tissues from explanted recipient hearts and atrial appendage samples obtained during coronary bypass graft operations were also examined and displayed varying amounts of $\mathrm{N}$-CAM immunoreactivity. We conclude that the expression of $\mathrm{N}-\mathrm{CAM}$ immunoreactivity and isoforms in the human heart is developmentally regulated and may be modulated by factors such as cardiac innervation and myocardial hypertrophy. (J. Clin. Invest. 1990. 86: 1293-1300.) Key words: cardiac • innervation $\bullet$ fetal $\bullet$ adhesion molecules
\end{abstract}

\section{Introduction}

Our knowledge of the factors modulating cardiac development and innervation is far from complete, but molecules involved in cell adhesion may be important. One of the molecules most likely to be involved in these processes is neural cell adhesion

Address reprint requests to Dr. John Wharton, Department of Histochemistry, Royal Postgraduate Medical School, Du Cane Road, London, W12 ONN, United Kingdom.

Received for publication 16 November 1989 and in revised form 29 May 1990.

J. Clin. Invest.

(c) The American Society for Clinical Investigation, Inc. 0021-9738/90/10/1293/08 $\$ 2.00$

Volume 86, October 1990, 1293-1300 molecule (N-CAM), ${ }^{1}$ which is a cell surface sialoglycoprotein that mediates adhesive interactions between cells in the nervous system and skeletal muscle (1-3). N-CAM occurs as several, structurally distinct, isoforms that are encoded by a single-copy gene and generated via alternative RNA splicing and polyadenylation, and by postranslational modifications of glycosylation, sulfation, and phosphorylation (4-6). N-CAM isoforms exhibit tissue-specific regional and developmental changes in expression (7-9), which are modulated by a variety of factors, including innervation, thyroid hormones and nerve growth factor (10-12).

Attention has focused mainly on the neural and skeletal muscle expression of N-CAM, but immunoreactivity has also been identified in the embryonic chicken $(13,7)$ and mouse heart (14). We have recently demonstrated that rat myocardium displays N-CAM immunoreactivity and exhibits temporal changes in both the localization and isoforms expressed (15). These developmentally regulated changes in cardiac N-CAM are comparable with those described during skeletal muscle myogenesis and are consistent with the proposal that $\mathrm{N}$-CAM expression may be important in cardiac morphogenesis and innervation (14).

In this study we have used immunohistochemical techniques to investigate the localization and isoforms of N-CAM present in the human heart during development and after extrinsic denervation in cardiac allografts.

\section{Methods}

Tissue preparation. Fresh cardiac and skeletal muscle samples were obtained from human fetuses at 7-24 wk gestation $(n=30)$ after legal abortion by uterine evacuation for medical reasons other than suspected cardiac abnormality. Cardiac samples were also obtained from patients undergoing coronary artery bypass graft operations ( $n=37$, aged 33-76 yr) and heart or heart-lung transplantation ( $n=25$, aged 1.4-59.0 yr). Recipient cardiac tissues were collected from 12 patients at primary heart or heart-lung transplantation (Table I; mean age \pm SEM; $25.6 \pm 5.5 \mathrm{yr}$ ). Allograft and recipient tissues were also obtained from 13 patients undergoing a second transplant procedure $(27.3 \pm 4.5 \mathrm{yr}), 8$ having received a heart-lung allograft and 5 a heart transplant $2 \mathrm{~d}$ to 91 mo earlier (Table II). Further tissue samples were obtained from transplant donor hearts and at postmortem from six cases without cardiac complications $(45.0 \pm 9.7 \mathrm{yr})$, after a 3-15-h delay between death and sampling (Table I). The collection of all human tissues followed the ethical standards of the institutions in which they were obtained.

1. Abbreviation used in this paper: N-CAM, neural cell adhesion molecule. 
Table I. Clinical Features of Patients

\begin{tabular}{cccc}
\hline No. Sex & Age & Transplant & Diagnosis or cause of death \\
\hline$y r$ &
\end{tabular}

Postmortem cases

$\begin{array}{lllll}\text { 1 } & \text { M } & 31 & - & \text { Road traffic accident } \\ 2 & \text { F } & 60 & - & \text { Hodgkin's disease } \\ 3 & \text { F } & 75 & - & \text { Septicemia } \\ 4 & \text { F } & 24 & - & \text { Asphyxia (hanging) } \\ 5 & \text { F } & 65 & - & \text { Glucagonoma } \\ 6 & \text { M } & 19 & - & \text { Road traffic accident }\end{array}$

Cardiac transplantation recipients

\begin{tabular}{rlrll} 
1 & F & 2 & H-L & Tricuspid atresia \\
2 & F & 1.4 & H-L & Dilated cardiomyopathy \\
3 & M & 59 & H & Ischemic heart disease \\
4 & M & 59 & H & Dilated cardiomyopathy \\
5 & M & 28 & H & Adriamycin cardiomyopathy \\
6 & M & 6 & H-L & Eisenmenger's syndrome \\
7 & F & 28 & H-L & Idiopathic pulmonary hemosiderosis \\
8 & M & 29 & H-L & Sarcoidosis \\
9 & F & 21 & H-L & Cystic fibrosis \\
10 & F & 14 & H-L & Cystic fibrosis \\
11 & F & 25 & H-L & Cystic fibrosis \\
12 & F & 35 & H-L & Primary pulmonary hypertension \\
\hline
\end{tabular}

$H$, heart transplant; $H-L$, heart-lung transplant.

Fetal hearts were processed as intact organs whereas selected regions were examined in the surgical, transplant, and postmortem cases, full-thickness transmural samples being obtained from the lateral walls of both ventricles, interventricular septum, papillary muscles, atria, and atrial appendages. Adjacent areas of each sample were taken for immunohistochemistry and Western blot analysis. Samples for immunohistochemistry were fixed by immersion in a modified Bouin's solution, rinsed in PBS containing $15 \%$ sucrose and $0.1 \%$ sodium azide and cryostat blocks were prepared as previously described (16).

Immunohistochemical studies. An indirect immunofluorescence technique was used to localize N-CAM immunoreactivity in tissue sections. Briefly, sections $(15 \mu \mathrm{m})$ thick were cut in a crysotat at $-25^{\circ} \mathrm{C}$, collected on poly-L-lysine-coated slides and air dried for $1 \mathrm{~h}$ at room temperature. The sections were then immersed in PBS containing $0.2 \%$ Triton $\mathrm{X}-100$ for $30 \mathrm{~min}$, rinsed in buffer, and stained with Pontamine sky blue (British Drug Houses, Poole, UK) to reduce background autofluorescence and counterstain elastic tissue. After rinsing in buffer, sections were incubated sequentially with diluted N-CAM antisera overnight at $4^{\circ} \mathrm{C}$ and then with fluorescein isothiocyanate-labeled goat anti-rabbit IgG (Miles Scientific, Slough, UK) diluted $1: 100$, for $1 \mathrm{~h}$ at room temperature. After rinsing, the preparations were mounted in glycerol mixed 2:1 with PBS and examined using a microscope (Olympus AH-2) equipped for epi-illumination. Controls included the omission of primary antiserum and replacing the primary antiserum with preimmune serum.

Antisera. Four primary N-CAM antisera were used, including rabbit anti-human N-CAM, D2 $(17,18)$ generously provided by Dr. E. Bock (University of Copenhagen, Copenhagen, Denmark); affinitypurified rabbit anti-chick N-CAM $(19,20)$ generously provided by Professor G. M. Edelman (The Rockefeller University, New York); and two mouse monoclonal antisera to human N-CAM. One of the monoclonal antisera was originally described as being directed against a human muscle-specific antigen, $5.1 \mathrm{H} 11,(21,22)$ which is now known to be human N-CAM (23). Antiserum to the general neuronal marker protein gene product 9.5 (PGP 9.5; Ultraclone, Isle of Wight, UK) was used to identify cardiac nerves (16) and the distribution. pattern of PGP 9.5- and N-CAM-immunoreactive nerves were compared in serial sections.

Immunoblot analysis. Protein extracts of cardiac tissues were prepared by homogenization and sonication at $4^{\circ} \mathrm{C}$ in equivalent volumes $(0.1 \mathrm{mg} / \mathrm{ml}$ ) of $1 \mathrm{M}$ Tris buffer ( $\mathrm{pH} \mathrm{7.4)}$ containing $1 \%$ NP-40 (Sigma Chemical Co., Poole, UK), $1 \mathrm{mM}$ phenylmethylsulfonyl chloride and $2.5 \mathrm{mM}$ EDTA. After standing for $1 \mathrm{~h}$ at $4^{\circ} \mathrm{C}$, the extracts were centrifuged at $25,000 \mathrm{~g}$ for $10 \mathrm{~min}$ and the supernatant was removed. To generate the desialo forms of N-CAM, neuraminidase (type $\mathrm{X}$, final concentration $0.5 \mathrm{U} / \mathrm{ml}$; Sigma Chemical Co.) was added to extracts in $2.5 \mathrm{mM}$ sodium acetate buffer (pH 5.0) for $1 \mathrm{~h}$ at $37^{\circ} \mathrm{C}$. N-CAM isoforms were separated from NP-40 extracts by SDS-PAGE (24). Ali-

Table II. Clinical Features of the Retransplant Patients

\begin{tabular}{|c|c|c|c|c|c|c|c|c|c|}
\hline \multicolumn{4}{|c|}{ Recipient } & \multicolumn{5}{|c|}{ Primary transplant } & \multirow[b]{2}{*}{$\begin{array}{l}\text { Secondary transplant } \\
\text { indication }\end{array}$} \\
\hline \multirow[t]{2}{*}{ No. } & Sex & Age & Diagnosis & Type & Donor sex & Age & $\begin{array}{l}\text { Ischemia } \\
\text { time }\end{array}$ & Duration & \\
\hline & & $y r$ & & & & $y r$ & $\min$ & mo & \\
\hline 1 & $\mathrm{~F}$ & 10 & PF & H-L & $\mathbf{M}$ & 5 & 220 & 1.3 & Rejection \\
\hline 2 & $\mathbf{F}$ & 25 & $\mathrm{CF}$ & $\mathrm{H}-\mathrm{L}$ & $\mathbf{M}$ & 8 & 180 & 8 & Recurrent infection \\
\hline 4 & $\mathbf{F}$ & 18 & PPH & H-L & $\mathbf{F}$ & 20 & 175 & 11 & OB \\
\hline 5 & $\mathbf{F}$ & 9 & $\mathrm{CONG}+\mathrm{PH}$ & H-L & $\mathbf{F}$ & 7 & 215 & 13 & OB \\
\hline 6 & $\mathbf{F}$ & 33 & PPH & H-L & $\mathbf{F}$ & 13 & 100 & 16 & OB \\
\hline 7 & $\mathbf{F}$ & 3 & PPH & H-L & $\mathbf{F}$ & 2.5 & 160 & 21 & OB \\
\hline 8 & $\mathbf{M}$ & 43 & IHD & H (Het) & $\mathbf{M}$ & 15 & 102 & 46 & Rejection \\
\hline 9 & $\mathbf{M}$ & 48 & IHD & H (Het) & $\mathbf{M}$ & 20 & 195 & 63 & Rejection \\
\hline 11 & $\mathbf{M}$ & 34 & $\mathbf{C M}$ & $\mathrm{H}$ (Orth) & $\mathrm{F}$ & 14 & 145 & 67 & Rejection \\
\hline 12 & $\mathbf{M}$ & 43 & IHD & H (Het) & $\mathbf{M}$ & 50 & 225 & $2 \mathrm{~d}$ & Rejection \\
\hline 13 & $\mathbf{F}$ & 17 & CF & H-L (2nd) & $\mathbf{M}$ & 12 & 220 & 12 & OB \\
\hline
\end{tabular}

$C F$, cystic fibrosis; $C M$, cardiomyopathy; $C O N G+P H$, congenital heart defect and pulmonary hypertension; $H(H e t)$, heterotopic heart transplant; $H(O r t h)$, orthotopic heart transplant; $H-L$, heart-lung transplant; $I H D$, Ischemic heart disease; $O B$, obliterative bronchiolitis; $P F$, pulmonary fibrosis; $P P H$, primary pulmonary hypertension. 
quots were then mixed with SDS sample buffer containing $80 \mathrm{mM}$ Tris (pH 6.8), 2\% SDS, and $1 \%$ glycerol, to which was added $1 \mathrm{mM}$ DTT and $0.02 \%$ bromophenol blue. The samples were heated to boiling point for 2 min, loaded on a 5\% SDS stacking gel according to equivalent wet weights of tissue, and electrophoresed in $7.5 \%$ polyacrylamide gels at $45 \mathrm{mV}$ together with prestained molecular weight markers (Sigma Chemical Co). Proteins were transferred to nitrocellulose paper (Anderman \& Co. Ltd., Kingston-upon-Thames, UK) overnight, at 30 $\mathrm{V}$ and $4^{\circ} \mathrm{C}$, according to the procedure of Towbin et al. (25). The nitrocellulose paper was subsequently incubated in PBS containing $2 \%$ casein (pH 7.2) for $1 \mathrm{~h}$ to inhibit nonspecific binding. N-CAM isoforms were identified by incubating the blot with mouse anti-human N-CAM antisera diluted 1:1000 in PBS containing $1 \%$ casein, for $1 \mathrm{~h}$ at room temperature. After washing in buffer, bound antibodies were detected by incubating the blot with purified goat anti-mouse IgG (heavy and light chain) peroxidase conjugate (Bio-Rad Laboratories Ltd., Hemel Hempstead, UK) diluted 1:1,000 in 0.5\% casein in PBS, for $1 \mathrm{~h}$ at room temperature, and the immunoglobulin complexes were visualized with $1 \mathrm{M}$ Tris-buffered saline containing methanol, $0.05 \%$ wt/vol 4 , chloro-1-napthol, and $0.05 \% \mathrm{vol} / \mathrm{vol}$ hydrogen peroxide.

\section{Results}

\section{Immunocytochemistry}

Fetal heart. N-CAM immunoreactivity was detected in the fetal heart at all stages in the gestational period examined (7-24 wk). Antisera to both human and chick N-CAM provided identical patterns of immunostaining. Myocardial cells throughout the atria and ventricles exhibited prominent sarcolemma immunoreactivity (Fig. 1, $A$ and $B$ ). Vascular smooth muscle in the aorta and coronary and pulmonary arteries was devoid of immunoreactivity. Immunostaining was concentrated in the sinus and atrioventricular nodes (Fig. $1 C$ ), whereas the ventricular conduction tissue displayed similar amounts of immunoreactivity to the adjacent myocardium. $\mathrm{N}-\mathrm{CAM}$ immunoreactivity was also localized to the developing cardiac innervation where it was associated with the surface of neuronal cell bodies, nerve trunks and fibers (Fig. $1 \mathrm{D}$ ). During early fetal development (7-10 wk gestation) immunostained nerves and ganglia were largely confined to the epicardium and connective tissue around the aorta and pulmonary artery and in the region of the sinus node. From 10-24 wk gestation, N-CAM immunoreactive nerves occurred with increasing frequency in the atria and surrounding coronary arteries in the ventricular epicardium and myocardium. N-CAM immunoreactivity was further localized to cells in the cusps of cardiac valves (Fig. $1 E$ ). Fetal skeletal muscle cells also exhibited N-CAM immunoreactivity.

Childhood and adult heart. In marked contrast to the fetal heart, the myocardium examined during childhood to adult life (1.4-75 yr) displayed relatively little sarcolemmal and intercalated disc N-CAM immunoreactivity (Fig. 2, $A-C$ ). Similar results were obtained from transplant donor tissues and postmortem cases where death was due to noncardiac causes. Myocardial N-CAM immunofluorescence staining was either undetectable or of very low intensity in the normal heart, whereas cardiac neuronal cell bodies, nerve trunks, and axons displayed N-CAM immunoreactivity throughout childhood and adult life (Fig. 2, $A-C$ ). The immunostaining of serial sections revealed that nerve fibers and fascicles displaying N-CAM or PGP 9.5 immunoreactivity exhibited a similar distribution pattern (Fig. 2, $C$ and $D$ ). Myocardial immunoreactivity was, however, detected in the atrial and ventricular myocardium of explanted recipient hearts sampled at trans- plantation (Table I, Fig. 3, $A-C$ ) and in right atrial appendage obtained from patients undergoing coronary artery bypass grafts. The extent of the myocardial immunoreactivity exhibited considerable variation, from a few scattered myocytes to large areas of myocardium showing sarcolemmal and intercalated disc immunostaining (Fig. 3, $A-C$ ). In the cases examined (Table I), the myocardial immunoreactivity appeared to be less extensive in tissues from patients with cystic fibrosis, sarcoidosis, and pulmonary hemosiderosis, where there was generally low intensity immunofluorescence staining of intercalated discs, than in cases with congenital heart defects, cardiomyopathy, and ischemic heart disease, in which large areas of myocardium exhibited both sarcolemmal and intercalated disc immunostaining.

Transplanted heart. Extensive myocardial N-CAM immunoreactivity was demonstrated in all the cardiac allografts examined from 5 wk to 91 mo after transplantation (Table II). The immunoreactivity was localized to both the intercalated discs and sarcolemma of myocytes, with contiguous staining throughout the atria and ventricles, in both heterotopic and orthotopic allografts (Fig. 4, $A-C$ ). The myocardial immunostaining detected in a single heterotopic allograft obtained $2 \mathrm{~d}$ after transplantation did, however, appear to be less intense, with fewer myocytes exhibiting immunoreactivity. As in the fetal and normal adult heart, N-CAM immunoreactivity was not detected in vascular smooth muscle, but was still displayed by nerves within the transplanted heart.

Immunoblotting. N-CAM immunoreactivity in the fetal heart migrated mainly as $120-, 145-$, and $150-\mathrm{kD}$ desialo isoforms with lower molecular weight peptides also occurring as 110 - and 115-kD bands (Fig. 5). These molecular forms differed from the main forms in skeletal muscle extracts (125-, $140-$, and $155-\mathrm{kD}$ ). Extracts of normal adult heart contained very little immunoreactivity, detected as $125-$ and $140-\mathrm{kD}$ isoforms, whereas allograft tissues were consistently found to contain substantial amounts of immunoreactivity, mainly as 120 - and 125-kD isoforms (Fig. 5). Variable levels of N-CAM isoforms were also demonstrated in the tissue extracts of primary explanted hearts and right atrial appendage samples.

\section{Discussion}

The present findings demonstrate that, as in the rat (15), myocytes and nerves in the developing human heart both display N-CAM immunoreactivity. Myocardial N-CAM was localized to the sarcolemma and exhibited developmental modulation, with extensive fetal expression and subsequent downregulation in the adult, where myocardial immunostaining was either weak or not detected. Similar temporal changes in N-CAM immunoreactivity have been found to occur during skeletal muscle morphogenesis, expression being suppressed once innervation and maturation are established $(10,18)$. Intercalated discs were not detected in immunostained sections of the fetal heart, presumably because there are few specialized intercellular contacts in early cardiac morphogenesis (26). Cells throughout the fetal myocardium and conduction system displayed sarcolemmal N-CAM immunoreactivity. This coincides with the early development of human cardiac innervation (27) and while it is uncertain whether any correlation exists between the two, regions destined to receive a dense innervation, such as the sinus and atrioventricular nodes, displayed prominent sarcolemmal N-CAM immunoreactivity. N-CAM expression appears to be a general feature of auto 

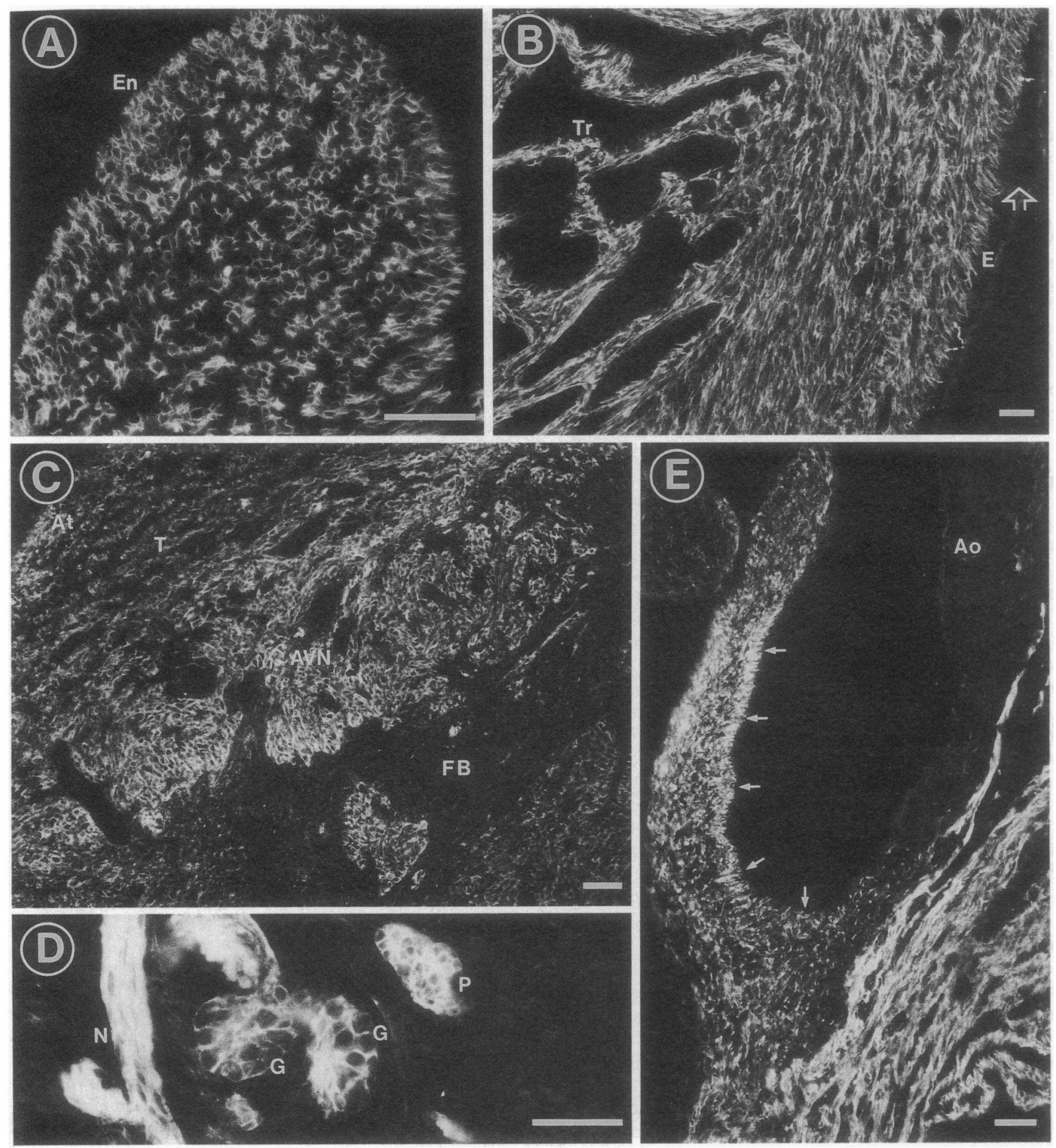

Figure 1. Immunofluorescence micrographs of sections of human fetal heart at $13 \mathrm{wk}(A, D$, and $E), 10 \mathrm{wk}(B)$, and 15 wk gestation $(C)$, showing N-CAM immunoreactivity. Myocardial cells in the atria $(A)$ and ventricles $(B)$ and cells in the atrioventricular node $(C, A V N)$ display sarcolemma immunoreactivity. Neuronal cells in cardiac ganglia $(g)$, nerve trunks $(n)$, and an associated paraganglion $(p)$, between the aorta and pulmonary artery, also display N-CAM immunoreactivity $(D)$, as do cells in aortic valve cusps $(E$, arrows). Vascular smooth muscle in the aorta $(E, A o)$ and branches of coronary arteries $(B$, arrowhead $)$ lack immunoreactivity. $E n$, endocardium; $T r$, trabeculae; $E$, epicardium; $A t$, atrial overlay cells; $T$, transitional cells; $F B$, fibrous body. Bar, $50 \mu \mathrm{m}$.

nomic and sensory nerves (28) and the cardiac nervous system is no exception, N-CAM immunoreactivity being localized to neuronal cell bodies, nerve fascicles and fibers in both the developing and adult human cardiac innervation. The temporal and spatial localization of N-CAM to the cardiac nervous system, as well as to the myocardium, is consistent with the proposal that N-CAM may be involved in homophilic cellular interactions in cardiac morphogenesis and innervation (14). In skeletal muscle N-CAM has been implicated in the processes of myoblast fusion (29) and nerve-muscle interaction $(3,30)$. Little direct evidence is available to substantiate a role for N-CAM in such processes in the heart, but N-CAM 

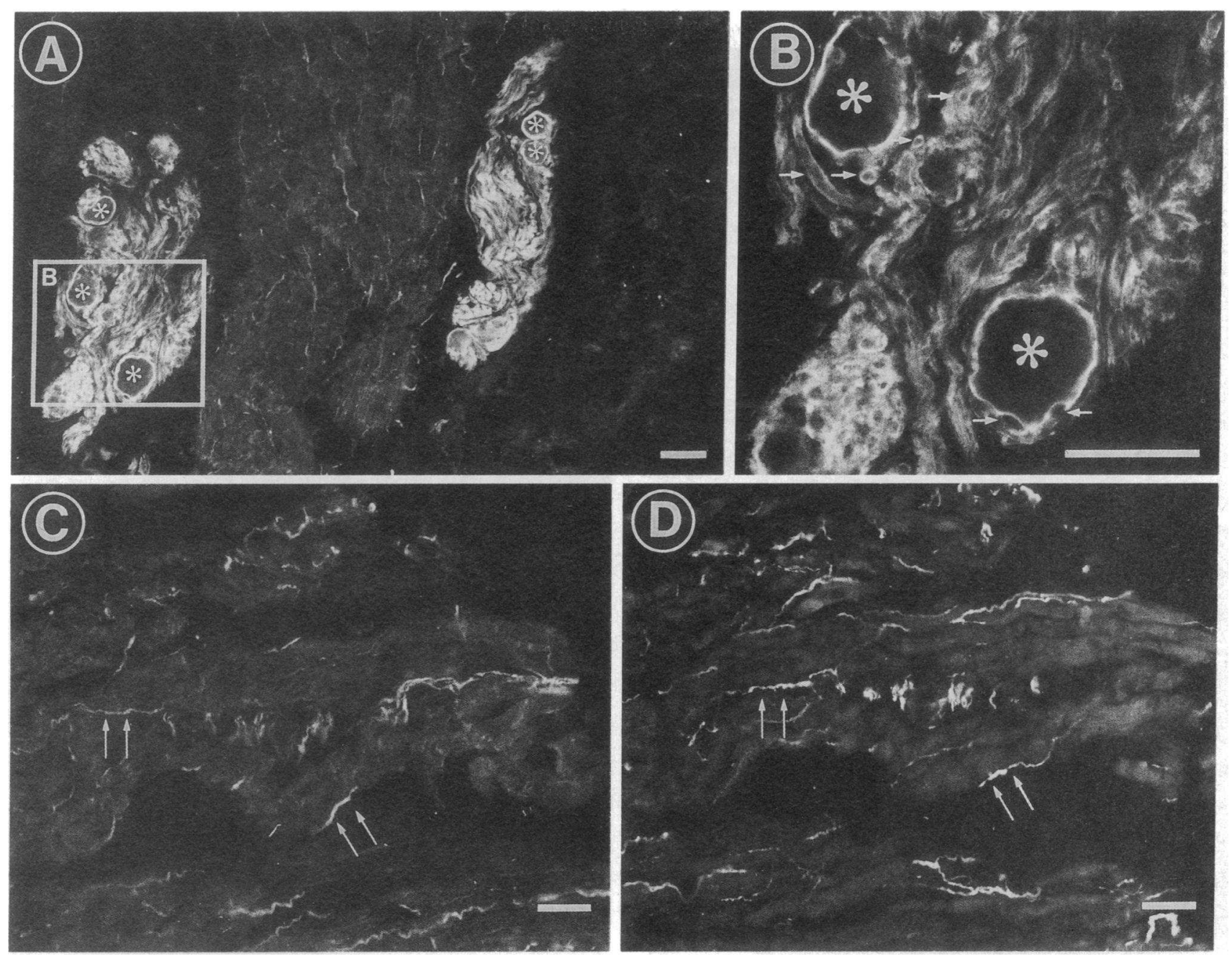

Figure 2. Immunofluorescence micrographs of sections from the left atrium $(A$ and $B$ ) of a transplant donor aged $20 \mathrm{yr}$ and right atrium $(C$ and $D$ ) of a postmortem case (No. 6, Table I) showing N-CAM $(A-C)$ and PGP 9.5 immunoreactivity $(D)$. N-CAM immunoreactivity is localized predominantly to the cardiac innervation, with the surface of neuronal cell bodies ( $A$ and $B$, asterisks), nerve trunks and axons (single arrows) exhibiting immunostaining. Serial sections of atrium contain nerve fibers and fascicles $(C$ and $D$, double arrows) which display immunoreactivity for both N-CAM $(C)$ and the general neuronal marker PGP $9.5(D)$. Bar, $50 \mu \mathrm{m}$.

antibodies have been shown to disrupt the adhesion of $\mathrm{N}-\mathrm{CAM}$ bearing vesicles to embryonic chicken cardiac muscle cells in vitro (14).

$\mathrm{N}-\mathrm{CAM}$ immunoreactivity was also localized to cells in the cusps of fetal heart valves. Valve cusps receive nerve fibers and contain a mixed population of cells comprising myocardial, smooth muscle, and interstitial cells, which possess contractile properties (31). The cells displaying N-CAM immunoreactivity were not specifically identified, but it is apparent that cardiac valves are not the passive structures they were once thought to be $(31,32)$ and $\mathrm{N}-\mathrm{CAM}$ might have a role in mediating cellular interactions in valve cusps.

Cardiac development in both the mouse (14) and rat (15) is accompanied by a transition of N-CAM isoforms from the main embryonic (145-150-kD) to early postnatal (125-kD) isoforms, and by a reduced level of N-CAM expression in the adult. Similar changes occur in skeletal muscle myogenesis, with the $140-\mathrm{kD}$ isoform present in myoblasts undergoing a transition to $125-$ and $155-\mathrm{kD}$ forms in myotubes. Developmental changes in N-CAM isoforms were also observed in the human heart, but due to the lack of normal tissue in the late fetal and neonatal period, the time course of isoform transition is less clear than in experimental animals. The major desialo isoforms in the fetal heart were 150,145 and $120 \mathrm{kD}$, with 115 and $110-\mathrm{kD}$ bands also present. In the normal adult only low levels of the 120- and $125-\mathrm{kD}$ isoforms were detected. The isoforms isolated from the human heart vary from those found in embryonic chicken $(7,33)$, mouse (14), and rat heart (15), as well as those in age-matched human skeletal muscle tissues, and may arise as a result of species- and/or tissue-specific processing of N-CAM polypeptides $(6,33)$.

Cardiac transplantation was accompanied by a marked and relatively rapid increase in myocardial N-CAM immunoreactivity, which was localized to the sarcolemma and intercalated discs and composed of 120-, 125-, and 115-kD isoforms. This may represent a response to the extrinsic denervation of the heart that occurs during transplantation since denervation and paralysis of skeletal muscle also results in the reexpression of N-CAM $(34,35)$. The $125-\mathrm{kD}$ N-CAM isoform, which is reexpressed in denervated skeletal muscle (10) and cardiac allografts, has been found to support neurite outgrowth (36) and may be involved in the process of innervation and nerve regeneration $(37,38)$. In contrast to transplanted hearts in experimental animals $(39,40)$ and denervated $(38)$ or regenerating 

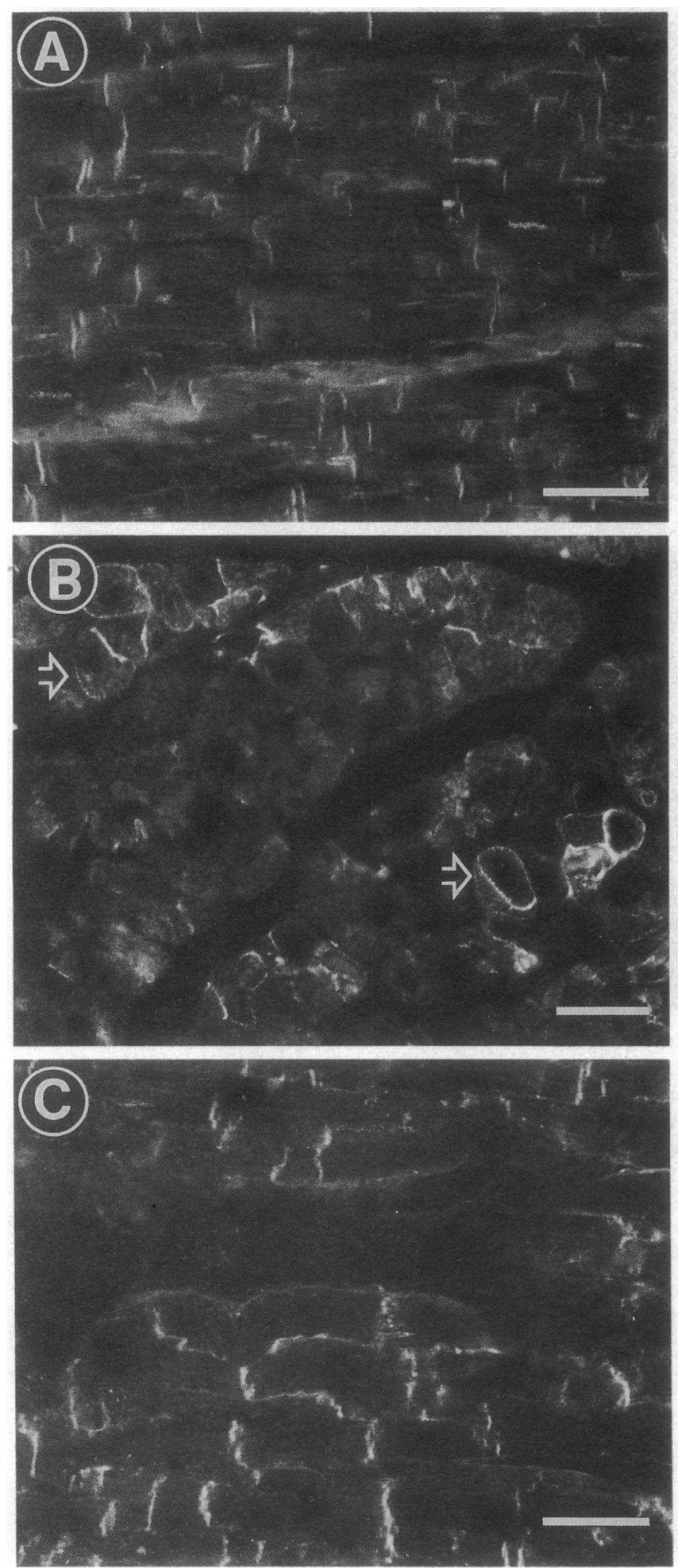

Figure 3. Immunofluorescence micrographs of sections from explanted hearts showing varying amounts of myocardial N-CAM immunoreactivity. Section of left ventricle posterior wall $(A)$ from a case of idiopathic pulmonary haemosiderosis (case no. 7, Table I) displaying relatively weak intercalated disc immunostaining. Sections of left atrium $(B)$ and right ventricle lateral wall $(C)$ from a case of Eisenmenger's syndrome (case no. 6, Table I) in which scattered myocytes display punctate sarcolemmal immunostaining ( $B$, arrowheads) and areas of myocardium exhibit both sarcolemmal and intercalated disc immunoreactivity $(C)$. Bar, $50 \mu \mathrm{m}$.
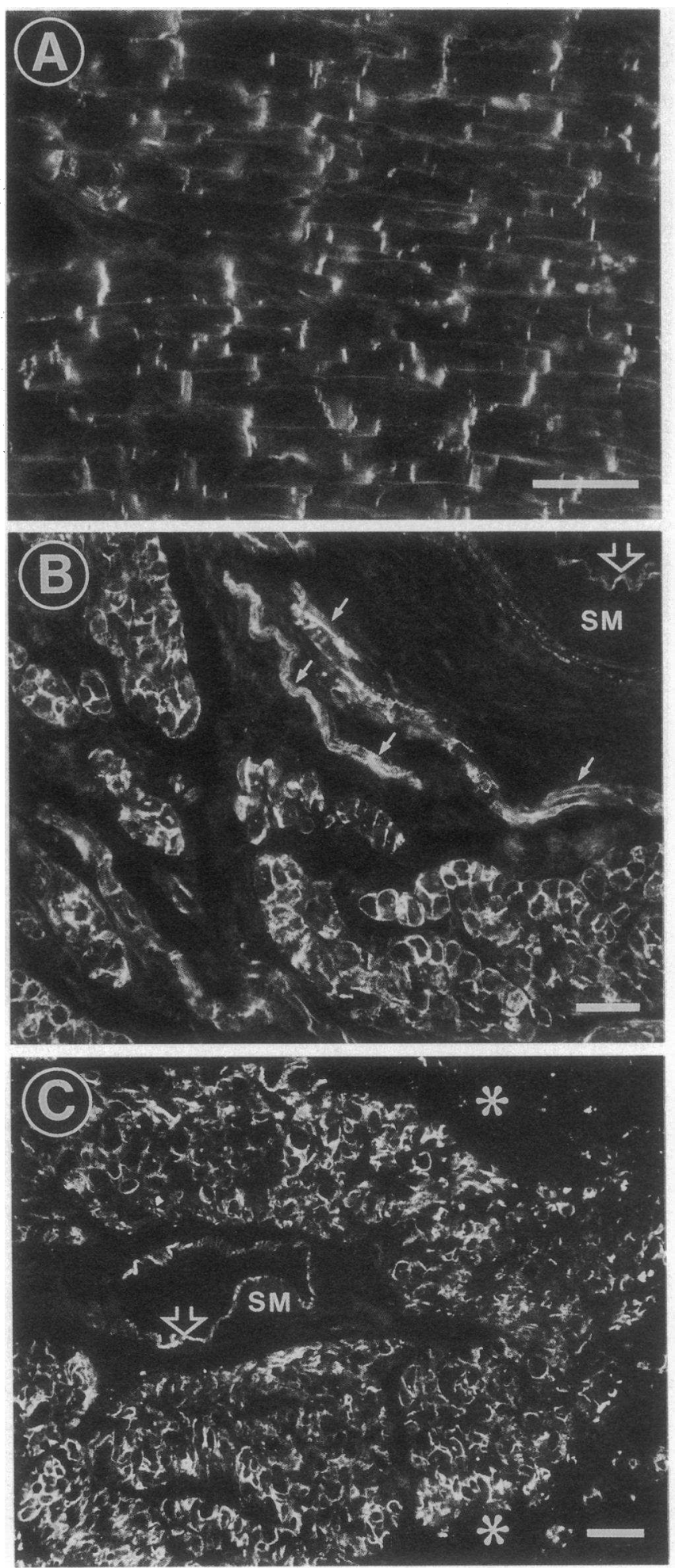

Figure 4. Immunofluorescence micrographs of sections of left ventricle papillary muscle ( $A$; case no. 3 , Table II), left atrium ( $B$; case no. 3 , Table II) and interventricular septum ( $C$; case no. 9, Table II) from cardiac allografts 10-63 mo after transplantation. The myocardium exhibits extensive N-CAM immunoreactivity, with contiguous intense immunostaining of intercalated discs and sarcolemma. Vascular smooth muscle $(\mathrm{sm})$ lacks immunoreactivity, but nerves are also immunostained $(B$, arrows). Islands of immunoreactive myocardium, with a central artery, surrounded by scarred, infarcted myo- 

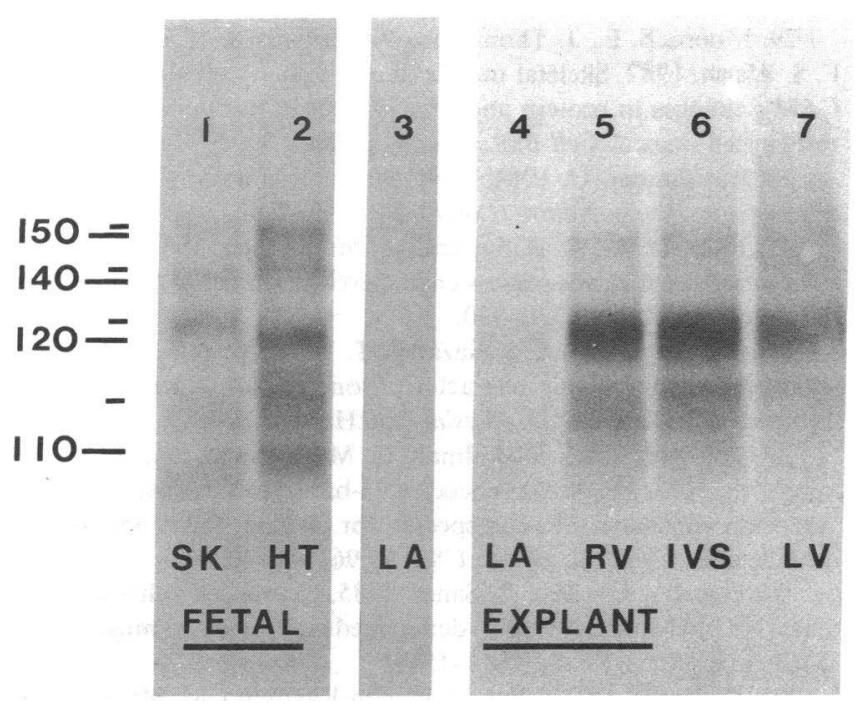

skeletal muscle (37), human cardiac allografts do not usually exhibit evidence of functional reinnervation (41) and this would seem to be consistent with the continued expression of myocardial N-CAM immunoreactivity in the transplanted heart. A 115-kD N-CAM isoform was prominent in both the developing and transplanted human heart and a secreted $\mathrm{N}$-CAM isoform of similar size has recently been identified (42), which may be involved in cellular-matrix interactions (43).

Our findings indicate that human myocardial N-CAM expression may be modulated by the innervation of the heart. Other factors such as hypertrophy could also have a modulatory influence, however, as indicated by the selective increase in N-CAM immunoreactivity which we have found in the hypertrophic myocardium of the rat heart following exposure to chronic hypoxia (44). Unlike skeletal muscle, the myocardium does not undergo regeneration and postnatal adaptation is via hypertrophy and fibrosis rather than hyperplasia. Myocardial hypertrophy is also a morphological feature of the transplanted heart and may arise in response to prolonged ischemia or the administration of immunosuppressive drugs which cause hypertension (45). Variable amounts of N-CAM immunoreactivity were detected in different forms of heart disease and, whereas no specific correlation was demonstrated, myocardial immunoreactivity did appear to be more extensive in cases where the heart was subject to an increased pressure or volume load. Note that the transplanted hearts were removed because of graft failure and other factors, such as rejection, could also influence N-CAM expression.

In conclusion, human myocardial N-CAM immunoreac-

cardium ( $C$, asterisks). The Pontamine sky blue counterstain provides a fluoresence staining of the elastic lamina in coronary arteries (B, arrowheads). Bar, $50 \mu \mathrm{m}$.
Figure 5. Western blot analysis of desialo $\mathrm{N}-\mathrm{CAM}$ isoforms in human fetal (12 wk gestation) skeletal muscle $(S K$, lane 1$)$ and heart ( $H T$, lane 2); transplant donor (lane 3); explanted recipient heart from a case of primary pulmonary hypertension (lanes 4-7; case no. 12, Table I) and cardiac allografts $2 \mathrm{~d}$, (lanes 8-10; case no. 12, Table II) and $63 \mathrm{mo}$ after transplantation (lanes 11 and 12; case no. 9, Table II). All the samples were loaded to an equivalent wet weight of tissue, with $30 \mu l$ of combined supernatant and SDS buffer added to each lane. $R A$, right atrium; $L A$, left atrium; $R V$, right ventricle; $L V$, left ventricle; $I V S$, interventricular septum.

tivity is subject to both temporal and spatial regulation and factors such as innervation and hypertrophy may well be involved in modulating N-CAM expression in the heart.

\section{Acknowledgments}

The authors wish to thank Professor G. M. Edelman (The Rockefeller University, New York) for generously providing the purified antichicken N-CAM IgG. We are also grateful to Mrs. Patricia Harley for technical assistance and Dr. Nick Banner for his comments on this manuscript.

The work was funded by grants from the Muscular Dystrophy Group of Great Britain, the Wellcome Trust, and the British Heart Foundation.

\section{References}

1. Rutishauser, U., M. Grumet, and G. M. Edelman. 1983. Neural cell adhesion molecule mediates initial interactions between spinal cord neurons and muscle cells in culture. J. Cell Biol. 97:145-152.

2. Edelman, G. M. 1986. Cell adhesion molecules in neural histogenesis. Annu. Rev. Physiol. 48:417-430.

3. Grumet, M., U. Rutishauser, and G. M. Edelman. 1982. Neural cell adhesion molecule is on embryonic muscle cells and mediates adhesion to nerve cells in vitro. Nature (Lond.). 295:693-695.

4. Barbas, J. A., J:-C. Chaix, M. Steinmetz, and C. Goridis. 1988. Differential splicing and alternative polyadenylation generates distinct NCAM transcripts and proteins in the mouse. EMBO (Eur. Mol. Biol. Organ.) J. 7:625-632.

5. Barton, C. H., G. Dickson, H. J. Gower, L. H. Rowett, W. Putt, V. Elsom, S. E. Moore, C. Goridis, and F. S. Walsh. 1988. Complete sequence and in vitro expression of a tissue-specific phosphatidylinositol-linked N-CAM isoform from skeletal muscle. Development. 104:165-173.

6. Nybroe, O., D. Linnemann, and E. Bock. 1988. N-CAM biosynthesis in brain. Neurochem. Int. 12:251-262.

7. Murray, B. A., G. C. Owens, E. A. Prediger, K. L. Crossin, B. A. Cunningham, and G. M. Edelman. 1986. Cell surface modulation of 
the neural cell adhesion molecule resulting from alternative mRNA splicing in a tissue-specific developmental sequence. J. Cell Biol. 103:1431-1439.

8. Dickson, G., H. J. Gower, C. H. Barton, H. M. Prentice, V. L. Elsom, S. E. Moore, R. D. Cox, C. Quinn, W. Putt, and F. S. Walsh. 1987. Human muscle neural cell adhesion molecule (N-CAM): identification of a muscle-specific sequence in the extracellular domain. Cell. 50:1119-1130.

9. Thompson, J., G. Dickson, S. E. Moore, H. J. Gower, W. Putt, J. G. Kenimer, C. H. Barton, and F. S. Walsh. 1989. Alternative splicing of the neural cell adhesion molecule gene generates variant extracellular domain structure in skeletal muscle and brain. Genes \& Dev. 3:348-357.

10. Covault, J., J. P. Merlie, C. Goridis, and J. R. Sanes. 1986. Molecular forms of N-CAM and its RNA in developing and denervated skeletal muscle. J. Cell Biol. 102:731-739.

11. Thompson, J., S. E. Moore, and F. S. Walsh. 1987. Thyroid hormones regulate expression of neural cell adhesion molecule in adult skeletal muscle. FEBS (Fed. Eur. Biochem. Soc.) Lett. 219:135-138.

12. Prentice, H. M., S. E. Moore, J. G. Dickson, P. Doherty, and F. S. Walsh. 1987. Nerve growth factor induced changes in neural cell adhesion molecule (N-CAM) in PC12 cells. EMBO (Eur. Mol. Biol. Organ.) J. 6:1859-1863.

13. Thiery, J-P., J-L. Duband, U. Rutishauser, and G. M. Edelman. 1982. Cell adhesion molecules in early chicken embryogenesis. Proc. Natl. Acad. Sci. USA. 79:6737-6741.

14. Hoffman, S., M. Grumet, and G. M. Edelman. 1985. Cell adhesion molecules in the histogenesis of nerve and muscle. In Cardiac Morphogenesis. V. J. Ferrans, G. Rosenquist, and C. Weinstein, editors. Elsevier Science Publishers, New York. 36-43.

15. Wharton, J., L. Gordon, F. S. Walsh, T. P. Flanigan, S. E. Moore, and J. M. Polak. 1989. Neural cell adhesion molecule (NCAM) expression during cardiac development in the rat. Brain Res. 483:170-176.

16. Wharton, J., S. Gulbenkian, A. Merighi, D. M. Kuhn, R. Jahn, K. M. Taylor, and J. M. Polak. 1988. Immunohistochemical and ultrastructural localization of peptide-containing nerves and myocardial cells in the human atrial appendage. Cell Tissue Res. 254:155-166.

17. Ibsen, I., V. Berezin, B. Norgaard-Pedersen, and E. Bock. 1983. Enzyme-linked immunosorbent assay of the D2-glycoprotein. $J$. Neurochem. 41:356-362.

18. Moore, S. E., and F. S. Walsh. 1985. Specific regulation of N-CAM/D2-CAM cell adhesion molecule during skeletal muscle development. EMBO (Eur. Mol. Biol. Organ.) J. 4:623-630.

19. Hoffman, S., B. C. Sorkin, P. C. White, R. Brackenbury, R. Mailhammer, U. Rutishauser, B. A. Cunningham, and G. M. Edelman. 1982. Chemical characterization of a neural cell adhesion molecule purified from embryonic brain membranes. J. Biol. Chem. 257:7720-7729.

20. Rutishauser, U., S. Hoffman, and G. M. Edelman. 1982. Binding properties of a cell adhesion molecule from neural tissue. Proc. Natl. Acad. Sci. USA. 79:685-689.

21. Walsh, F. S., and M. A. Ritter. 1981. Surface antigen differentiation during human myogenesis in culture. Nature (Lond.). 289:6064.

22. Hurko, O., and F. S. Walsh. 1983. Human fetal specific antigen is restricted to regenerating myofibres in diseased adult muscle. Neurology. 33:737-734.

23. Walsh, F. S., G. Dickson, S. E. Moore, and C. H. Barton. 1989. Unmasking N-CAM. Nature (Lond.). 339:516.

24. Laemmli, U. K. 1970. Cleavage of structural proteins during the assembly of the head of bacteriophage T4. Nature (Lond.). 227:680-685

25. Towbin, H., T. Staehelin, and J. Gordon. 1979. Electrophoretic transfer of proteins from polyacrylamide gels to nitrocellulose sheets. Procedure and some applications. Proc. Natl. Acad. Sci. USA. 76:4350-4354.
26. McNutt, N. S. 1970. Ultrastucture of intercellular junctions in adult and developing cardiac muscle. Am. J. Cardiol. 25:169-183.

27. Wharton, J., R. H. Anderson, R. Espejo, A. Smith, R. Penketh, and J. M. Polak. 1988. Development of human cardiac innervation. Circulation. 78:II-557. (Abstr.)

28. Mirsky, R., K. R. Jessen, M. Shachner, and C. Goridis. 1986. Distribution of the cell adhesion molecules N-CAM and $\mathrm{L} 1$ in peripheral neurons and glia in adult rats. J. Neurocytol. 15:799-815.

29. Moore, S. E., J. Thompson, V. Kirkness, J. G. Dickson, and F. S. Walsh. 1987. Skeletal muscle neural cell adhesion molecule (NCAM): changes in protein and mRNA species during myogenesis of muscle cell lines. J. Cell Biol. 105:1377-1386.

30. Rutishauser, U. 1984. Developmental biology of a neural cell adhesion molecule. Nature (Lond.). 310:549-554.

31. Filip, D. A., A. Radu, and M. Simionescu. 1986. Interstitial cells of the heart valves possess characteristics similar to smooth muscle cells. Circ. Res. 59:310-320.

32. Pinto, J. E. B., A. J. Nazarali, T. Torda, and J. M. Saavedra. 1989. Autoradiographic characterization of $\beta$-adrenoceptors in rat heart valve leaflets. Am. J. Physiol. 256:H821-H827.

33. Prediger, E. A., S. Hoffman, G. M. Edelman, and B. A. Cunningham. 1988. Four exons encode a 93-base insert in three neural cell adhesion molecule mRNAs specific for chicken heart and skeletal muscle. Proc. Natl. Acad. Sci. USA. 85:9616-9620.

34. Covault, J., and J. R. Sanes. 1985. Neural cell adhesion molecule (N-CAM) accumulates in denervated and paralysed muscle. Proc. Natl. Acad. Sci. USA. 82:4544-4548.

35. Rieger, F., M. Nicolet, M. Pincon-Raymond, M. Murawsky, G. Levi, and G. M. Edelman. 1988. Distribution and role in regeneration of N-CAM in the basal laminae of muscle and Schwann cells. J. Cell Biol. 107:707-719.

36. Doherty, P., C. H. Barton, G. Dickson, P. Seaton, L. H. Rowett, S. E. Moore, H. J. Gower, and F. S. Walsh. 1989. Neuronal processes of outgrowth of human sensory neurons on monolayers of cells transfected with cDNAs for five human N-CAM isoforms. J. Cell Biol. 109:789-798.

37. Daniloff, J. K., G. Levi, M. Grumet, F. Rieger, and G. M. Edelman. 1986. Altered expression of neural cell adhesion molecule induced by nerve injury and repair. J. Cell Biol. 103:929-945.

38. Covault, J., J. M. Cunningham, and J. R. Sanes. 1987. Neurite outgrowth on cryostat sections of innervated and denervated skeletal muscle. J. Cell Biol. 105:2479-2488.

39. Kontos, H. A., M. D. Thames, and R. R. Lower. 1970. Responses to electrical and reflex autonomic stimulation in dogs with cardiac transplantation before and after reinnervation. J. Thorac. Cardiovasc. Surg. 59:382-392.

40. Kondo, Y., J. L. Mathey, and J. D. Hardy. 1972. Autonomic reinnervation of cardiac transplant: further observations in dogs and rhesus monkeys. Ann. Surg. 176:42-48.

41. Wharton, J., J. M. Polak, L. Gordon, N. R. Banner, D. R. Springall, M. Rose, A. Khagani, J. Wallwork, and M. H. Yacoub. 1989. Immunohistochemical demonstration of human cardiac innervation before and after transplantation. Circ. Res. 66:900-912.

42. Gower, H. J., C. H. Barton, V. L. Elsom, J. Thompson, S. E. Moore, G. Dickson, and F. S. Walsh. 1988. Alternative splicing generates a secreted form of N-CAM in muscle and brain. Cell. 55:955-964.

43. Booth C. M., and M. C. Brown. 1988. Localization of neural cell adhesion molecule in denervated muscle to both the plasma membrane and extracellular compartments by immuno-electron microscopy. Neuroscience. 27:699-709.

44. Wharton, J., L. Gordon, F. S. Walsh, T. P. Flanigan, S. E. Moore, R. Winter, and J. M. Polak. 1988. Re-expression of neural cell adhesion molecule (N-CAM) in hypertrophic myocardium. FASEB (Fed. Au. Soc. Exp. Biol.) J. 3:903A. (Abstr.)

45. Imakita, M., H. D. Tazelaar, R. A. Rowan, M. A. Masek, and M. E. Billingham. 1987. Myocyte hypertrophy in the transplanted heart. A morphometric analysis. Transplantation. 43:839-842. 